\title{
ABOUT THE NECESSITY TO DETERMINE THE TECHNICAL CONDITION OF BUILDINGS OF STRATEGIC IMPORTANCE IN UNGHENI DISTRICT FROM REPUBLIC OF MOLDOVA
}

\author{
Ion Rusu*, ORCID: 0000-0002-7507-638X, \\ Ion Crețu, ORCID: 0000-0003-3174-2536 \\ Technical University of Moldova, 168, Stefan cel Mare Bd., Chisinau, Republic of Moldova \\ ${ }^{*}$ Corresponding author: Ion Rusu, ion.rusu@dmmc.utm.md \\ Received: 03. 24. 2021 \\ Accepted: 04. 28. 2021
}

\begin{abstract}
This paper deals with the need to determine the technical condition of strategic buildings, blocks of flats, which are in a precarious condition as well as engineering networks located within the Ungheni district. The article refers to the real present situation of buildings and housing stock from Ungheni municipality, including their periods of commissioning. Current research methods of buildings are exposed, being listed their advantages and disadvantages.
\end{abstract}

Keywords: hazard risk, engineering networks, methods, technical expertise, cracks, consolidation.

\section{Introduction}

Concrete, reinforced concrete and masonry constructions are not eternal and indestructible. Over the time, they all are subjected to degradation, some of them being slower while others faster. Among the conditions that contribute to reducing the service life and the existence of constructions, firstly is considered to be the action of natural and technological environmental agents and their own shortcomings created by the existence of induced defects within the design process, designing, execution and exploitation. Firstly, among the benefits of prolonging life there could be identified the examination of technical condition, maintenance and rehabilitation activities, consolidation intended to extend the service life of buildings subject to degradation.

Degradation of buildings can be defined as the gradual loss of physical and functional qualities that characterizes the aptitude to exploit them.

The degradation process most often starts from the contact surfaces of the buildings with the environment. In the case of buildings, such manifestations show the gradual change in the color of paints and dyes, cracking and chipping of plasters, wetting and staining of surfaces, the appearance of efflorescence, rust stains, of rot, etc. In the event of cracks in the roof layers it degrades substantially during freeze-thaw cycles with the possible penetration of rainwater into the building or those from snowmelt, etc.

Progression of degradation towards the inside of the constructive components affects over the time the safety of constructions at critical points, cracks may appear in the load-bearing elements of the building, where the latter guarantees the taking over of all 
construction load and their transmission to the foundation ground. The most dangerous form of degradation process evolution is the appearance of crack, preceding the destruction of the element.

Together with climatic factors (wetting and drying, repeated freeze-thaw cycles, the action of aggressive environments, micro- and macroorganisms, etc.) construction degradation is also caused by possible hazard risk (earthquakes, landslides, floods, fires, etc.). Ungheni, Nisporeni and Hâncești districts are located at a distance of $150 \ldots 200 \mathrm{~km}$ from Vrancea district in Romania where earthquakes often occur. They are also felt on the territory of the Republic of Moldova (January 31, 2020, Chisinau magnitude of 5.4 on the Richter scale; April 24, 2020, Chisinau magnitude 5.0 degrees on the Richter scale; June 25, 2020, Chisinau magnitude 4.6 on the Richter scale) [1].

In the area of these districts several natural disasters occurred: floods (July 6, 2010, the villages of Nemțeni, Obileni, Sărăteni and Cotul Morii) [2]; Landslides (Leușeni village, 1997-1999) [3]. These natural disasters have contributed also to partial degradation, but in some cases, the total destruction of constructions, installations, engineering networks, intended to ensure the normal conditions of life and activity of human beings.

The loss of human beings, material goods, the harvest, etc., which occur as a result of natural hazards, requires to determine the possible risks and propose measures to prevent them. The cost of the measures, on the prevention of possible risks due to natural disasters is much smaller than the liquidation of the consequences following them.

Based on these considerations, assessment of the condition of constructions, installations and engineering networks, primarily of those strategic importance buildings (local public administration buildings, hospitals, kindergartens and schools, engineering networks for the supply of electricity and heat, water, natural gas) from this area, represents a challenging problem.

The purpose of the planned studies and research.

To ensure sufficient minimum life and activity conditions for population in the Ungheni district area, in case of possible hazard risk, it is necessary to appreciate, first of all, the technical condition of strategic buildings, installations and engineering networks and the development of measures for their safe exploitation.

Studies and research objectives

The main objectives are:

- technical expertise and assessment of technical condition of buildings, installations and engineering networks in this area;

- drawing up lists of defects of inspected buildings, installations and networks;

- elaboration of recommendations on the consolidation, repair and renovation of such buildings, installations and networks;

- other recommendations and proposals according to the request of local public administration.

1. The current situation of buildings and engineering networks in Ungheni.

Structural analysis of constructions (with their expertise), to reduce material damage and loss of life, must be carried out on buildings of major importance or at increased risk of natural hazards:

- buildings where local decisions are proposed: local public administration buildings Ungheni district (the activity and decision-making in exceptional situations should not be stopped); 
- buildings, where employees are located, which intervene promptly during natural disasters: Civil Protection and Exceptional Situations Service and Ungheni Police;

- educational institutions. In Ungheni municipality there are:

$>6$ kindergartens;

$>6$ school institutions;

$>4$ secondary education institutions, colleges, etc .;

$>2$ extracurricular activities institutions;

- health care buildings (in case of possible natural hazard, with possible victims, they should be treated safely: IMSP Ungheni District Hospital, Consultative diagnostic center, etc.);

- housing stock, which is in a precarious condition.

Housing stock of Ungheni municipality consists of 12719 individual houses and residential apartments in blocks of flats up to 9 floors, with a total area of 649.4 thousand $\mathrm{m}^{2}$, the information is presented in Table 1 [4]. In this table there are also indicated the connections of houses to engineering networks.

Ungheni municipality has 6 sectors with a total population of about 38.2 thousand inhabitants (Figure 1).

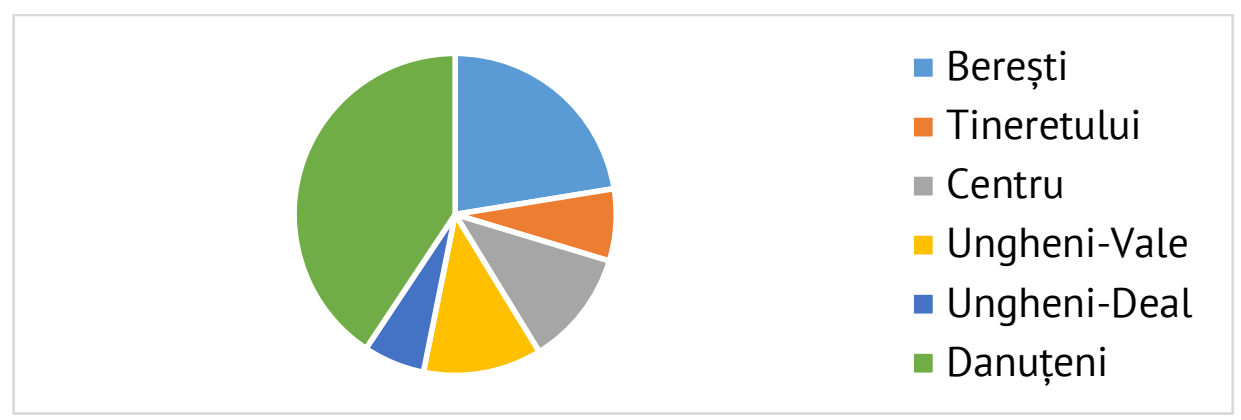

Figure 1. Sectors (micro-districts) of Ungheni municipality.

Distribution of housing stock by sectors is presented in Table 2 and Table 3 [4]. Location of residential blocks with over 23,000 inhabitants (which constitutes over $60 \%$ of the total population) is concentrated in the Tineretului and Centru sectors, so, the blocks located in these sectors must be examined primarily.

Table 4 [4] shows the years for the commissioning of residential blocks. According to these data, over $14 \%$ of the total number of blocks of flats were built by the 1970 s, and most of them require reconstruction and repair. About $62 \%$ of the blocks of flats were built in the years 1970-1990 which need to be inspected.

To ensure the security for the population, it is necessary to analyze all engineering networks. Ungheni municipality is connected, practically, to all networks:

- Water supply networks:

$>$ Water supply network of Ungheni municipality provides the distribution of drinking, technical and irrigation water. Water supply of the locality constitutes Prut river accumulation basin;

$>$ In addition, there are 271 wells in Ungheni;

$>$ The number of water supply systems -1 ;

$>$ The length of water distribution networks - $137.5 \mathrm{~km}$, including in reconstruction $1.7 \mathrm{~km}$; 
The general characteristic of housing stock according to the number of floors, connecting engineering networks

No. The name of the indices thousand $m^{2}$ total area 649,4
(12719 houses/apartments)

1. Total housing stock, inclusive 100

2. According to the number of floors:

\begin{tabular}{clll}
\hline 2.1. & - individual houses & 234,6 & 36,1 \\
\hline 2.2. & - 2-3 floors & 30,52 & 4,7 \\
\hline 2.3. & - 4-5 floors & 186,77 & 28,8 \\
\hline 2.4. & - over 5 floors & 197,51 & 30,4 \\
\hline 3. & Connecting engineering networks & & \\
\hline 3.1. & - water supply & 471,4 & 72,6 \\
\hline 3.2. & - sewerage & 455,9 & 70,2 \\
\hline 3.3. & - central heating supply & 427,3 & 65,8 \\
\hline 3.4. & - natural gas supply & 593,5 & 91,4 \\
\hline
\end{tabular}

Table 2

Distribution of the housing stock by sectors (area, thousand $\boldsymbol{m}^{2}$ )

\begin{tabular}{|c|c|c|c|c|c|c|c|}
\hline \multirow{4}{*}{ No. } & \multirow{4}{*}{ Sector name } & \multicolumn{6}{|c|}{ Existing housing stock, thousand $m^{2}$} \\
\hline & & \multirow{3}{*}{ Total } & \multicolumn{5}{|c|}{ inclusive } \\
\hline & & & \multirow{2}{*}{$\begin{array}{c}\text { indivi- } \\
\text { dual } \\
\text { houses }\end{array}$} & \multicolumn{4}{|c|}{ multi-story houses } \\
\hline & & & & Total & $\begin{array}{c}2-3 \\
\text { floors }\end{array}$ & $\begin{array}{c}\text { 4-5 } \\
\text { floors }\end{array}$ & $\begin{array}{c}5-9 \\
\text { floors }\end{array}$ \\
\hline 1. & Berești & 58,8 & 55,45 & 3,35 & 0 & 3,35 & 0 \\
\hline 2. & Tineretului & 214,29 & 1,55 & 212,74 & 5,91 & 82,4 & 124,43 \\
\hline 3. & Centru & 184,84 & 30,61 & 154,23 & 18,93 & 62,22 & 73,08 \\
\hline 4. & Ungheni-Vale & 27,8 & 21,9 & 5,9 & 3,03 & 2,87 & 0 \\
\hline 5. & Ungheni-Deal & 18,8 & 18,8 & 0 & 0 & 0 & 0 \\
\hline 6. & Danuţeni & 144,87 & 106,29 & 38,58 & 2,65 & 35,93 & 0 \\
\hline & Total & 649,4 & 234,6 & 414,8 & 30,52 & 186,77 & 197,51 \\
\hline
\end{tabular}


The structure of housing stock of Ungheni municipality (number of individual houses/apartments)

\begin{tabular}{|c|c|c|c|c|c|c|c|c|c|}
\hline \multirow{4}{*}{ No. } & & & \multicolumn{7}{|c|}{ Existing housing stock, individual houses/apartments } \\
\hline & & & \multirow{3}{*}{ Total } & \multicolumn{6}{|c|}{ inclusive } \\
\hline & \multirow{2}{*}{\multicolumn{2}{|c|}{ Sector name }} & & \multirow{2}{*}{$\begin{array}{c}\text { indivi- } \\
\text { dual } \\
\text { houses }\end{array}$} & \multicolumn{5}{|c|}{ multi-story houses } \\
\hline & & & & & Total & \multicolumn{2}{|c|}{$\begin{array}{c}2-3 \\
\text { floors }\end{array}$} & $\begin{array}{c}\text { 4-5 } \\
\text { floors }\end{array}$ & $\begin{array}{c}5-9 \\
\text { floors }\end{array}$ \\
\hline 1. & \multicolumn{2}{|l|}{ Bereşti } & 1060 & 1000 & 60 & \multicolumn{2}{|c|}{0} & 60 & 0 \\
\hline 2. & \multicolumn{2}{|c|}{ Tineretului } & 4448 & 28 & 4420 & \multicolumn{2}{|c|}{176} & 2082 & 2162 \\
\hline 3. & \multicolumn{2}{|l|}{ Centru } & 3493 & 552 & 2941 & \multicolumn{2}{|c|}{393} & 1161 & 1387 \\
\hline 4. & \multicolumn{2}{|c|}{ Ungheni-Vale } & 515 & 395 & 120 & \multicolumn{2}{|c|}{60} & 60 & 0 \\
\hline 5. & \multicolumn{2}{|c|}{ Ungheni-Deal } & 339 & 339 & 0 & \multicolumn{2}{|c|}{0} & 0 & 0 \\
\hline 6. & \multicolumn{2}{|l|}{ Danuţeni } & 2864 & 1917 & 947 & \multicolumn{2}{|c|}{90} & 857 & 0 \\
\hline & Total & & 12719 & 4231 & 8488 & & 9 & 4220 & 3549 \\
\hline & Dis & tributiol & of of housi & ig stock t & y sectors & accordi & g to com & imissionin & Table 4 \\
\hline & & $\begin{array}{r}\text { Exi } \\
\text { housil }\end{array}$ & $\begin{array}{l}\text { isting } \\
\text { ing stock }\end{array}$ & & & ears of $c$ & mmission & ning & \\
\hline $\mathrm{No}$ & Sector & & & 1950 & 1970 & 197 & -1990 & 199 & -2014 \\
\hline & & $\begin{array}{l}\text { apart- } \\
\text { ments }\end{array}$ & $\begin{array}{c}\text { Total } \\
\text { area } \boldsymbol{m}^{2}\end{array}$ & $\begin{array}{l}\text { No. } \\
\text { apart- } \\
\text { ments }\end{array}$ & $\begin{array}{c}\text { Total } \\
\text { area } \\
m^{2}\end{array}$ & $\begin{array}{l}\text { No. } \\
\text { apart- } \\
\text { ments }\end{array}$ & $\begin{array}{c}\text { Total } \\
\text { area } \\
m^{2}\end{array}$ & $\begin{array}{l}\text { No. } \\
\text { apart- } \\
\text { ments }\end{array}$ & $\begin{array}{c}\text { Total } \\
\text { area } \\
m^{2}\end{array}$ \\
\hline 1. & Bereşti & 60 & 3346 & - & - & - & - & 60 & 3346 \\
\hline 2. & Tineretului & 4420 & 212745 & 696 & 33500 & 2946 & 141798 & 778 & 37447 \\
\hline 3. & Centru & 2941 & 154233 & 491 & 25749 & 1278 & 67022 & 1172 & 61463 \\
\hline 4. & $\begin{array}{l}\text { Ungheni- } \\
\text { Vale }\end{array}$ & 120 & 5901 & 36 & 1170 & 84 & 4130 & - & - \\
\hline 5. & $\begin{array}{l}\text { Ungheni- } \\
\text { Deal }\end{array}$ & - & - & - & - & - & - & - & - \\
\hline 6. & Danuţeni & 947 & 38576 & - & - & 947 & 38576 & - & - \\
\hline & Total & 8488 & 414801 & 1223 & 60419 & 5255 & 251526 & 2010 & 102256 \\
\hline
\end{tabular}


The length of the transport water networks in a line $-17.1 \mathrm{~km}$;

$>$ The number of artesian wells - 5;

$>$ The number of treatment stations - 2;

$>$ The capacity of the water treatment stations - 15.5 thousand $m^{3}$ in 24 hours;

$>$ The volume of water captured from surface water sources - 1771.4 thousand $\mathrm{m}^{3}$ (water is not captured from artesian wells).

- Sewerage networks:

$>$ Ungheni municipality has 3 main sewer collectors;

$>$ The number of sewerage systems -1 ;

$>$ Wastewater treatment station -1 ;

$>$ Project capacity of the wastewater treatment station -15.0 thousand $\mathrm{m}^{3} / 24$ hours, real 2.2 thousand $m^{3} / 24$ hours;

$>$ Total length of sewerage networks $-66 \mathrm{~km}$;

$>$ The number of wastewater pumping stations - 3, including in operation 3;

$>$ The volume of wastewater discharged into the centralized sewer system is about -803.2 thousand $\mathrm{m}^{3} /$ year.

- Heat and natural gas supply networks:

$>$ Heat energy supply networks was built in 1970-1980;

$>$ Heat supply system was operated for about 20 years without considerable capital repairs. So, heat supply centralized sources and mainstream heat supply networks have reached an unsatisfactory state;

$>$ Currently, the heat energy supply of residential and social blocks as well as communal enterprises is performed from the boiler houses;

$>$ Total boilers houses - 13 (of which 3 do not work) intended for heating social buildings;

> The residential blocks are connected to the boilers houses around 10-20\%;

$>$ The natural gas supply is ensured by medium pressure gas pipelines, with a length of $40.3 \mathrm{~km}$ and low pressure gas pipelines with a length of $99.8 \mathrm{~km}$.

- Electricity supply networks:

$>$ Ungheni municipality is connected to the North Electricity Distribution Network System for the supply of electricity at the voltage of $35 \mathrm{kV}$ and 110 $k V$;

$>110 \mathrm{kV}$ overhead line, located on the territory of Ungheni municipality and district has a length of $5 \mathrm{~km}$, and that of $35 \mathrm{kV}-20 \mathrm{~km}$;

$>$ The $10 \mathrm{kV}$ underground cables have a length of $128 \mathrm{~km}$, and the $6 \mathrm{kV}$ underground cables - $2.42 \mathrm{~km}$;

$>$ The $10 \mathrm{kV}$ and $6 \mathrm{kV}$ overhead lines are $21 \mathrm{~km}$ and $2 \mathrm{~km}$ long, respectively;

$>$ The medium voltage network of the locality supplies 119 transformation stations of which 47 are intended for residential consumers;

$>$ Low voltage network is intended for residential and non-industrial consumers as well as street lighting with 350 metal and reinforced concrete pillars, and in more remote areas 310 wooden pillars.

For the good operation of all engineering networks they must be inspected in time and, if necessary, measures have to be taken to prevent damage. In this case, in the event of natural hazard loss of life and property damage will be minimal or they will even be avoided. 


\section{Current methods for researching the technical condition of engineering constructions, installations and networks.}

Currently, there are several diagnostic methods $[5,6]$, which can be used to determine the technical condition of strategic importance constructions, installations and engineering networks in Ungheni district. Some of these will be discussed below.

Non-destructive methods.

The use of non-destructive methods makes it possible to both detect and locate defects as well as the assessment of the condition of building materials. Problems that occur when diagnosing constructions made it necessary to develop efficient methods, easy to apply and which, may be able to provide as complete data as possible on changes in the structure of materials, without influencing the condition of the building elements or materials.

Non-destructive investigation techniques aim to evaluate the characteristics of materials, so that the types of structural damage and their location can be detected. In addition to known non-destructive methods (especially ultrasonic), researchers are working on the application of new non-destructive methods, based on modern techniques with great development in other fields, but which have also found interesting applications in the field of construction measurements. These are methods based on the propagation of signals in building materials.

Ultrasonic pulse method.

It is the most used, it benefits from the development and improvement of the measuring device and a large volume of experimental data, which allows a good knowledge of how it is applied, its advantages and limitations.

The determination of degraded areas is based on the different ways of propagating ultrasound in solid environment and in air. The propagation time between the transmitting and the receiving transducer is measured, by direct or diagonal transmission, by comparison between the supposedly cracked areas and the non-cracked areas. Propagation time increases in degraded areas, due to the propagation mode, due to ultrasound, which bypasses cracks and microcracks. If the element has no degradations, the propagation of the waves is faster.

The advantages of this method are:

- it allows to establish the existence of areas with degradation (respectively cracks) and their location;

- the method can be used on the construction surface, on elements or structures of any shape or size, including those with a single accessible face;

- does not require complicated preparations;

- measurements are made quickly;

- the measuring device is relatively simple and has an average cost.

The disadvantages of the method are related to the complexity of data processing, which must take into account a large number of factors that influence the results.

Ultrasound investigation methods are most indicated in these cases. However, their application to masonry in natural rock or brick blocks presents difficulties, because both the brick and the connecting mortar, especially after their implementation, a heterogeneous element with a very high inhomogeneity is obtained. It is very difficult to find cracks in this case. Only masonry up to $1 \mathrm{~m}$ thick can be inspected with this method, thus limiting structural investigations to thin or monolithic elements. 
Seismic method: impact - echo.

Mechanical waves with a frequency from $300 \mathrm{~Hz}$ to $3 \mathrm{kHz}$, are usually generated with a "hammer" on the surface of the structural element. The waves propagate through the element and are received by one or more receivers.

Longitudinal wave propagation time, the fastest of them, is measured between transmitter and receiver. The speed of the wave, thus calculated, depends on the properties of the material, but it is also influenced by gaps, cracks or unfilled joints. Such situations cause deviations in wave propagation, thus reducing speed.

The seismic method allows the differentiation between the surfaces of different materials or structures (e.g. multi-layer masonry, filled holes, seams). Because the results depend on the mechanical properties, the method is very useful. Large gaps inside the element can also be detected. The seismic method can also be used to verify the efficiency of injections intended to increase the strength of masonry.

Quantitative ultrasound method.

The ultrasonic quantitative method is based on the "pulse-echo" measurement technique. Mode of propagation of ultrasonic frequency pulses (20 kHz - $200 \mathrm{kHz})$, transmitted to concrete or other material by mechanical coupling, depending on the characteristics of the material. The quality and defects of the material influence the speed of propagation, attenuation, and receive waveform. In this way, the cracking state of the material can be determined. The basic impediment is the separation of incorrect frequencies, which occur due to the inhomogeneity of the materials and which overlap the impulse harmonics carrying information on material defects. To solve the problem, complex mathematical calculations are used by averaging the power for each component of the signal.

This method, which requires special equipment different from the current one and equipped with computing technology, has proven its usefulness in detecting cracks and their evolution, when detecting damage in the freeze-thaw process, inspecting the strands, including in the anchorage areas.

Magnetic method.

For constructions diagnostics there has been used the method of included metal bodies detecting by using a device called a "pahometer". This method is based on perturbing the magnetic field, generated by a coil, in the presence of a metallic element. The disturbance is proportional to the size of the object and the proximity of the transducer. The transducer is directional, so the deviation is important when its longitudinal axis of the metal object are collinear.

The device allows to obtain favorable results to detect both beams and metal columns as well as the steel anchors in the stone walls. The device, equipped with a computer, visualizes the position, the diameter and processes the data.

Electromagnetic detection is recommended even in cases where certainty is required and there are no hidden metal objects, which may confuse the application of other methods.

\section{Conclusion}

- The bibliographic studies and the current state of the constructions, installations and engineering networks confirm that in the process of 
exploitation and under the influence of climatic factors and natural disasters they gradually degrade;

- Currently, there are several non-destructive and destructive methods, which allow to assess the degree of degradation of different materials from which constructions are built, installations and engineering networks with the forecast of safe operation term;

- The expertise of technical condition of constructions, installations and engineering networks as well as drawing up lists of their defects will allow the development of measures to ensure their safe operation.

Acknowledgments. This publication/material has been produced with the assistance of the European Union. The contents of this publication are the sole responsibility of Rusu Ion, Crețu Ion /Technical University of Moldova and can in no way be taken to reflect the views of the European Union or of the Joint Operational Programme Romania-Moldova 2014-2020 management structures.

\section{References}

1. https://diez.md/2020/02/11/pamantul-nu-doarme-lista-tuturor-cutremurelor-care-s-au-resimtit-inmoldova-in-ultimii-cinci-ani/ (access 24.10.2020);

2. https://agora.md/stiri/47391/opt-ani-de-la-cele-mai-mari-inundatii-din-istoria-republicii-moldova (access 12.11.2020);

3. https://point.md/ru/novosti/proisshestviya/pericol-de-alunecari-de-teren-pentru-mai-multe-localitai-dinara (access 15.10.2020);

4. The general urban plan of Ungheni municipality.

5. Iorga F. Diagnosticarea construcțiilor. Metode moderne [Construction diagnostics. Modern methods]. Revista Construcțiilor. București, nr. 48, mai 2009, pp. 72-78;

6. lacubovskii R., Bulanov I., Oliper I. Metody obsledovanija metallicheskih, zhelezobetonnyh i kamennyh konstrukcij [Inspection methods for metal, reinforced concrete and masonry constructions]. In: Molodoj uchenyj, 2015, № 23 (103), pp. 283-287 (in Russian). 